\title{
ELS EPÍTETS DELS ARTISTES BAIXMEDIEVALS AL SERVEI DELS PODERS REIAL I MUNICIPAL
}

\section{EPITHETS OF LATE MEDIEVAL ARTISTS AT THE SERVICE OF THE ROYAL AND LOCAL POWER}

\author{
Francesc Granell Sales \\ Universitat de València \\ francesc.granell@uv.es
}

Resum: Aquest article estudia els adjectius que van rebre els artistes que treballaren per al rei i per a les elits ciutadanes en els territoris de parla catalana durant els segles XIV i XV. En particular, se n'hi examinen dos: apte i subtil. Les notícies exhumades per uns altres especialistes fins al moment permeten comprendre'ls en el propi context documental. Ací es compara el seu significat amb uns altres exemples de la literatura baixmedieval de la Corona d'Aragó i es du a terme una aproximació històrica com a paraules que al-ludien a la perícia de l'artista i que van ser escollides amb una finalitat. Participaren i repercutiren, per tant, en la relació històrica de l'artista amb el client, d'entre els quals sobresortí el rei Pere el Cerimoniós. Les definicions que oferim complementen les que s'especifiquen als diccionaris històrics i subratllen la consideració específica que es tenia de les qualitats d'un artista.

Paraules clau: destresa artística, història de les paraules, poder reial, Corona d'Aragó, art baixmedieval, apte, subtil.

Abstract: This article studies the adjectives of the artists who worked at the service of the king and the local elites in the Catalan-speaking countries during the I4th and I5th centuries. It examines specifically two of them: apt and subtle. Textual records that have been published by other specialists enable us to understand these adjectives in their own documentary context. This paper also compares their meaning with other examples from the late medieval literature in the Crown of Aragon. We carry out an approach to their meaning as words that referred to the artistic skill and as words that were chosen with a concrete purpose. Therefore, they had repercussions in the historical engagement between the artist and the patron among who Peter the Ceremonious stood out. The definitions that we expose complement those which are spe- 
Francesc Granell Sales

Els epitets dels artistes baixmedievals al servei dels poders reial $i$ municipal

cified in the historical dictionaries and they highlight the specific consideration of the artistic abilities.

Key words: artistic skill, word history, royal power, Crown of Aragon, late medieval art, apt, subtle.

\section{$\cos \cos$}

\section{INTRODUCCIÓ}

L'historiador de l'art Julius von Schlosser, membre de l'Escola de Viena, va publicar una recopilació documental que incloïa notícies on alguns noms d'artistes medievals eren qualificats mitjançant epítets laudatoris, com, per exemple, egregius o elegans (Schlosser I896). El lector actual pot entendre aquestes adulacions com a símptomes d'una valoració social excel.lent del subjecte. No obstant això, s'ha demostrat que la pervivència de convencionalismes retòrics de l'antiguitat llatina i de pautes d'escriptura d'hagiografies va propiciar la manera de redactar-les (Muratova I986: 57-58). El present estudi té en compte qui expedeix els documents, a qui van dirigits i amb quina finalitat, com a factors que condicionen el significat d'uns epítets que participen i repercuteixen en la producció artística. Concretament, l'article estudia els qualificatius que reberen els artistes que treballaren per als reis i les institucions municipals dels territoris de parla catalana de la Corona d'Aragó i se'n dilucida el significat en el període cronològic que abraça la baixa edat mitjana.

La presència d'aquests epítets en diferents tipologies documentals i literàries possibilita la comparació del sentit que els atorguen diversos autors, fins i tot en els casos en què l'adjectiu no va adjuntat al nom d'un artífex. Com que són paraules que descriuen la perícia de l'artista, es pretén dilucidar quines facultats es destaquen i si aquestes guarden relació amb la personalitat artística de l'autor, considerant que pot ser un factor que influïsca en la relació de l'artífex amb el patró o el client. És per això que, en última instància, l'aproximació conjectural es fa envers uns vocables que poden aportar informació sobre la valoració social de l'artista en unes coordenades geogràfiques i històriques determinades.

El registre dels epítets s'ha fet a partir de les notícies sobre artistes medievals citades en articles o compendiades en reculls documentals, entre els quals destaquen, els Documents per a la història de la cultura catalana medieval (Rubió i Lluch 200o) i els Documents de la pintura valenciana medieval i moderna (Aliaga, Company \& To- 
losa 2005 i 20II). Les definicions s'han cercat i contrastat amb diccionaris normatius, descriptius, etimològics i històrics. Una especial utilitat a l'hora de ponderar l'ús de les paraules en diferents contextos textuals l'ha proporcionada el Corpus Informatitzat del Català Antic, un projecte que compendia textos escrits en llengua catalana des del segle XI fins al XviII i que està dirigit pels professors Joan Torruella, Manuel Pérez Saldanya i Josep Martines. Així doncs, fem servir les fonts literàries — novel-les, tractats, cròniques, hagiografies i enciclopèdies - com un mitjà per a fer història, una manera de procedir compartida per estudis que connecten la literatura i la història de l'art (Serra Desfilis 2005; García Marsilla 20II; Izquierdo Aranda 2013). Es troben més prop del mètode que ací se segueix uns altres estudis que han analitzat el vocabulari de les destreses artístiques en l'edat mitjana europea, com els de Mortet (I9II), Muratova (1986) i Perkinson (2002), i en l'edat moderna (Marr, Garrod \& Marcaida 2019). L'estructura que plantegem s'organitza en dos apartats que corresponen als dos mots que s'han detectat amb major assiduïtat, apte i subtil, cadascun dels quals es defineix a partir del significat que s'albira en cada cas particular i se'n compara el sentit en diverses fonts escrites.

\section{APTE}

Les notícies sobre artistes de la Corona d'Aragó en la baixa edat mitjana no són massa específiques a l'hora de descriure'ns qüestions que concerneixen el seu talent, la seua tècnica i la valoració social del seu art. L'ús dels epítets laudatoris que acompanyaven el nom de l'artista pot esdevenir útil en aquest sentit si es té en compte que informen d'unes determinades qualitats del subjecte en relació amb la seua aptitud professional. S'incloïen en ordres dirigides a l'artífex o a les autoritats ciutadanes, així com en les actes dels consells municipals, si bé hi ha casos puntuals apercebuts en plets judicials. En pocs mots, es troben en escrits administratius, els marges de difusió dels quals estaven acotats per la naturalesa documental mateixa. De manera que els adjectius que s'adjuntaven al nom no eren casuals i, a banda, tampoc corresponien a tradicions literàries convencionalitzades. I és que, com ja han suggerit determinats especialistes, s'han d'entendre com a mostres d'estima per la perícia de l'artista i de reconeixement pel seu ofici (Serra Desfilis 20II: 64-67; Español Beltrán 1997: I03-I05). Aquestes paraules de la perícia eren escollides de manera conscient dins d'un ventall de possibilitats que sembla gairebé prototípic en l'àmbit dels oficis artístics: abte, subtil, sufficient, sabut, subtil artifici, subtil enginy, entre altres. 
Francesc Granell Sales

Els epitets dels artistes baixmedievals al servei dels poders reial i municipal

Ladjectiu apte - $\mathrm{O}$ abte — té el sentit de «capaç i dispost convenientment per qualque cosa» (DCVB, s.v. apte). ${ }^{1} \mathrm{El}$ significat es constata d'una manera evident en els casos en què el mot és precedit o succeït per un altre sinònim qualificatiu. «Un bon tros de drap de vellut negre, apte o bastant per un gipó» era el premi que s'atorgava en el certamen poètic Obres o trobes en lahors de la Verge Maria del I474 (Ferrando I983: 158). Així doncs, el guanyador de la competició rebia un tros de vellut que havia de bastar (DCVB, s.v. bastant) per a confeccionar el gipó, una tela de vestir selecta. De la mateixa manera, apte es podia aplicar a la disposició d'una persona envers un afer. El teòleg Bernat Oliver suplica a Déu que tinga paciència amb ell perquè no es creu «abte e suficient de retre compte e raó d'aquella. Car los meus pecats són tals e tants, que bonament no han fi ne compte» (Oliver 1929: 64).

Entre les paraules registrades per a descriure un artista medieval, apte es repeteix amb assiduïtat i, amb relació amb el que hem dit més amunt, indica que l'artífex posseeix una capacitat operativa adequada. En 1373 el rei Pere el Cerimoniós escriu una carta dirigida als jurats, al justícia i als prohoms d'Albocàsser perquè s'havia destituït Domingo Valls, "pintor de Tortosa e de casa nostra", de l'enllestiment d'un retaule. S'hi fa constar que Valls insta els qui l'havien destituït a contactar amb «un maestre que fos abte e bo de la seua art» perquè comprovara si els materials i els colors utilitzats eren els acordats $\mathrm{i}$, a més, a ponderar si aquest mestre el podria ajudar a acabar l'obra. Seguidament, el monarca recomana, per a aquesta empresa, Llorenç Saragossà, «lo millor pintor que en aquesta ciutat sia", com el mestre que devia realitzar el peritatge del retaule que s'estava enllestint, atés que no pot ajudar a acabar-lo perquè es troba enfeinat a Barcelona (citat per Aliaga, Company \& Tolosa 2005: 223).

De la notícia s'infereix que Llorenç Saragossà acompleix els requisits d'«abte e bo" perquè se suposa que és un mestre capacitat per a jutjar el treball de Domingo Valls. Al llarg de la seua vida, Saragossà, natural de Cariñena, va ser un pintor requerit a les ciutats de València i Barcelona. Entorn als 25 anys d'edat, degué instal.lar el seu obrador a València d'on hagué de fugir cap al Principat amb motiu de la guerra amb Castella (García Marsilla 20I5: I06). La demanda del mercat artístic barceloní propiciaria l'encàrrec de treballs, potser com a associat o com a colllaborador dels Serra o de Ramon Destorrents (Pitarch 1979, 198I i 200I; Arciniega García 1995; Alcoy 2005; Aliaga 2009). En I374, el Consell de València acorda que s'atorguen uns incentius a Llorenç Saragossà perquè torne a la ciutat del Túria i és en aquest acord on es repeteix l'epítet abans emprat pel Cerimoniós, alhora que també se n'hi acobla un altre: «de fer

I. Hi ha més exemples que es fan ressò d'aquesta accepció del terme en el repertori de grups de sinònims de Curt Wittlin (I99I: I49). 
o donar alcun avantatge o gràcia a.n Lorenç Çaragoça, pintor, lo qual és molt subtil e apte en aquell offici» (citat per Aliaga, Company \& Tolosa 2005: 228). Ací l'ús d'apte torna a evidenciar la valoració òptima per la capacitat operativa del pintor; els consellers valencians el consideren un artífex competent per a l'exercici de la pintura fins al punt que l'incentiven perquè marxe de Barcelona per a instal.lar-se a la seua ciutat.

Tanmateix, la cerca del mateix adjectiu en diversos documents i contextos literaris incita a pensar en un significat complementari del terme. En el Curial e Güelfa (c. I443) abte està reservat per als personatges de la novel.la que gaudeixen d'una condició social superior. De bon començament, des que Güelfa, filla del marqués de Monferrat, s'enamora de Curial, aleshores un orfe jove d'origen humil acollit pel marqués, l'instiga que assolisca un bon estatus, llavors es "tornà molt prudent e abte» atés que començà a aprendre a cantar i a tocar instruments, així com a "cavalcar, trobar, dançar, júnyer e totes altres abteses que a noble jove e valerós se pertanyian». D'aquesta manera, se'l veia "créxer en bellesa e en virtut» (Ferrando 2007: 48). Güelfa s'havia enamorat de Curial amb anterioritat i aquest ja estava instruït en gramàtica, lògica, retòrica i filosofia, a banda de ser poeta, bell, savi, secret i valerós. Però necessitava que començara a ser un cavaller abte perquè la societat reconeguera el seu amor i el seu possible matrimoni. El coneixement i la pràctica de les «abteses», ${ }^{2}$ per tant, l'ajuden en aquesta empresa d'adquisició d'honor i de dignitat.

L'elevada freqüència amb què l'adjectiu s'empra al llarg de la novel.la no obsta perquè sempre estiga acoblat als personatges nobles i, de fet, l'accepció que en primer lloc haviem citat, la que designa la capacitat del subjecte —l'única que es referencia al diccionari Alcover-Moll—, no esdevé completament satisfactòria. El cavaller Gerardo de Perúgia és «molt abte», car té el valor d'enfrontar-se a Curial i a tres cavallers catalans (Ferrando 2007: II8). «Abta» és Làquesis, filla del duc de Baviera, perquè quan Curial entra a la seua cambra: «[...] se començà a meravellar molt, no solament de la bellesa de Làquesis, mas encara de la sua abtesa, ajustant a açò que ell no creya que pus abta donzella ne pus bella hagués en lo món» (Ferrando 2007: 82). I la mateixa Làquesis, qui s'enamorà de Curial, va ser objecte d'espionatge amb motiu de la gelosia de Güelfa, ja que s'havia de comprovar "com d'abta és Làquesis» (Ferrando 2007: 128).

Nogensmenys, el Curial no és l'única novel.la en què es documenta aquest adjectiu. En el Tirant lo Blanch de Joanot Martorell (c. I460) el protagonista també és descrit per mitjà del susdit epítet: «aquell famós cavaller Tirant lo Blach, qui de ànimo

2. Per a Pere Despuig la vida cortesana es fonamenta en un desengany, ja que hom hi accedeix gràcies als favors dels poderosos: «Pus que bondat neç abtesa / no val tant com la favor, / vul servir sa gran altessa / e pel mon cridar: favor!» (Ferrando 1983: 263).

Caplletra 70 (Primavera, 2021), p. 33-52 
Francesc Granell Sales

Els epitets dels artistes baixmedievals al servei dels poders reial i municipal

e benignitat passava tots los altres cavallers, abte e destre més que tot altre» (Martorell 2004: 1507). A més, uns altres tipus de testimonis confirmen l'ús del terme apte com un adjectiu que refereix a una qualitat d'estatus, respectada i, inclús, honorífica. En una missiva expedida l'any 1343 per voluntat del rei Pere el Cerimoniós es disposa atorgar a un cavaller, anomenat Villalba, el castell de Santueri, a Mallorca, però, en cas que el dit Villalba es negue a rebre'l, «liurats lo dit castell, ab la dita retinença e servents, a algun fill de cavaller apte qui sia de casa nostra» (citat per Ensenyat Pujol 1997: 106I07). Igualment, és prou significativa la presència reiterada del qualificatiu en l'Arbre d'Honor de Gabriel Turell (I47I), un tractat d'heràldica i un manual de principis i normes de la gentilesa, on es disserta sobre la condició honorífica de la noblesa i de la cavalleria. Es pot exemplificar amb una de les oracions que tracta sobre la noblesa dels animals que es representen en les armes de cases senyorials: «Los aucels són de més noblesa que les salvatgines; és la rahó que tenen llur natura pus apte e acostada als alements més nobles, qui és l'ayra e lo foch» (Turell 1992: 6I).

Després de considerar aquesta accepció del terme, amb una presència notable en novel.les i tractats de cavalleria baixmedievals, es comprén millor el seu significat quan acompanya el nom d'un artista. Vegem-ne unes mostres. En I4Io el Consell de València, palesant un gest de compassió, acorda la concessió d'unes cambres a Marçal de Sax, reconegut pintor forà de la primera generació del gòtic internacional (Saralegui 1952 i 1954), perquè poguera disposar d'una estança on viure. En l'escrit (citat per Aliaga, Company \& Tolosa 20II: 247) s'evoca el dit pintor d'una manera particular:

\footnotetext{
Derrerament lo present Consell, havent compassió a la necessitat que en sa persona pasava en via de malaltia e de pobrea maestre Marçal, abte pintor e molt loat de ses obres e doctrina donada a molts de sa art, atorgà e tant com al Consell de la ciutat plauria e no pus lo dit mestre Marçal hagués son statge e habitació en les cambres contigües a la casa sobirana del pes de la farina de la dita ciutat, les quals cambres són d'aquell alberch que era estat comprat del honorable en Ramon Guillem Català per créxer lo patí del dit pes.
}

En l'acord s'entreveu que Marçal de Sax es trobava en una situació d'indigència causada per una malaltia que li impedia la pràctica del seu ofici, i és per això que l'ús del qualificatiu abte s'interpreta com una característica de la reputació del pintor relacionada amb la seua aptitud professional, sobretot si atenem a la locució laudatòria que se segueix immediatament: «molt loat de ses obres e doctrinada donada a molts de sa art".

De la reputació d'un altre pintor, el francoflamenc Jacques Coene (Dubreuil 1987: II3-I56), en sentí parlar el rei Joan el Caçador per part dels seus brodadors. En I388 el monarca sol.licita al vescomte de Roda que contacte amb Coene perquè 
necessita un pintor capacitat per a la representació de persones (citat per Madurell i Marimón 1952: 89):

Nos havem mester I bon pintor per als nostres brodadors, los quals dien que a París ne ha I fort abte appellat Iaco Conno. Per què us manam que.l veiats e mirets en sa obra si és bé abte $\mathrm{e}$, specialment, que sàpia ben formar e pròpriament divisar figures de persones; e resemblar fisonomies de cares. E, si u fa, tenets ab ell manera que.l haiam de present, car nós li farem semblants profits que acostumam de donar als dits nostres brodadors e, si per aventura aquest no podets haver, procurats-ne un altre lo pus apte que se puxa, car fort lo havem necessari. ${ }^{3}$

En les tres vegades que s'especifica el qualificatiu apte es troba implícita l'allusió a la reputació de l'artista. Els qui informen Joan I són coneixedors del prestigi artístic de Jacques Coene i així li ho transmeten al rei; no obstant això, el rei vol assegurar-se'n, fent enviar el vescomte perquè observe les figures humanes que són representades pel pintor.

Un altre testimoni el trobem en el nomenament de Bernat Boix com a mestre d'obres dels murs de la ciutat de València en 1376. En l'acta del Consell és descrit: «maestre de obres d'edificis, molt abte e sufficient en aquella art» (citat per Serra Desfilis 20II: 72). Si tinguéssem en compte que abte descriu la capacitat i disposició de Boix per al seu ofici, l'adjectiu sufficient estaria redundant en el mateix significat perquè es refereix a "capaç, apte, idoni» (DA, s.v. suficient). I en aquest cas no hauríem de buscar un significat diferent als dos adjectius, ja que la construcció de binomis sinonímics en els segles XIV i XV era habitual amb motiu que els mots eren polisèmics i s'havien d'eliminar ambigüitats (Wittlin I99I: 65). Per això, l'expressió «molt abte e sufficient» equival ací a una mateixa cosa.

Creiem, però, que cada cas hauria d'analitzar-se en el seu context i no tots els binomis eren equivalents. De fet, aquests dos adjectius, apte e suficient, s'especificaven a l'hora d'escollir les persones que volien optar a càrrecs polítics del municipi o cerimonials de l'entorn àulic (citat per Arnall i Juan 2000: doc. 236; López Rodríguez 2004: doc. 79). Feien referència, doncs, tant a la particular facultat requerida com a la dignitat laboral que se'n deriva? No és facil posicionar-s'hi taxativament, però, en aquest sentit, cal tenir en compte que la fórmula podria equivaldre a digne e suficient en un context documental semblant. Així, per a designar la persona que pretenia

3. Per formar es pot entendre "fer quelcom donant-li forma pròpia» (DCVB, s.v. formar); per divisar "adornar d'emblemes i figures ornamentals» ( $D C V B$, s.v. divisar); i per ressemblar: "parèixer-se, tenir semblança» $(D C V B$, s.v. ressemblar). Per tant, el que es demana és la representació coherent, respecte a la realitat, de figures i rostres humans. No ens sembla que es referisca al retrat individualitzat ni en viu, uns paràmetres artístics que tardaran a posar-se en pràctica a la Corona d'Aragó.

Caplletra 70 (Primavera, 2021), p. 33-52 
Francesc Granell Sales

Els epitets dels artistes baixmedievals al servei dels poders reial $i$ municipal

optar a ser jurat de la vila d'Alzira, el Regiment dels officis de la insigne vil.la d'Algezira estipula: "[...] aquell qui volrà ésser col-locat novament o promogut al ofici de jurat si serà atrobat digne e sufficient» (Lairón Pla 200I: I76). ${ }^{4}$

En definitiva, la definició del mot apte que proporciona el diccionari («capaç i dispost convenientment per qualque cosa») esdevé incompleta en el context d'alguns documents que versen sobre artistes de la baixa edat mitjana. I és que quan el qualificatiu es particularitza com una característica d'un artista, també pot entendre's que aquest gaudeix d'una reputació adquirida per la seua experiència laboral i que, gràcies a aquesta, està capacitat per a dur endavant el treball en qüestió. És el cas de l'epítet assignat al mestre d'obres Joan del Poyo quan aquest fa unes determinades exigències al Consell en I4I8 i li són acceptades perquè convé a la fama i als interessos de la ciutat: «un dels pus abtes, singulars e famosos mestres que sien de sa art e offici en aquest Regne». En el raonament els jurats valoraven la "gran e singular sufficiència, abtea e expertea del dit mestre [...] per son famós exercici qu.ell és molt congoxat per molta notable gent a fer moltes notables obres en diverses parts de la dita ciutat e regne d'aquella» (citat per Serra Desfilis I994: II3-II4).

\section{SUBTIL}

De la mateixa manera que fins ara s'ha procedit, es contrastaran les definicions del terme subtil que ofereixen els diccionaris amb les notícies que descriuen les qualitats d'una persona amb motiu que, en acabat, se'n dilucide el significat en qualitat de lloança d'un artista. Així, les diverses accepcions de subtil varien depenent del recull que es consulte. D'entrada, cal puntualitzar que sotil, en concret, té el sentit de «baix de qualitat; de poca vàlua» ( $D C V B$, s.v. sotil) $\mathrm{i}$, per tant, aquest no és el qualificatiu que al.ludeix a les característiques d'un artista. ${ }^{5}$ Les dues accepcions que guarden relació

4. Encara, els jurats de València envien una carta en I42I als missatgers de la Generalitat en la cort del rei perquè no s'havia respectat la persona nomenada com a protonotari del monarca: «Oh! Quina esperança poden haver los valencians d'ésser promoguts per confiança de servir, si els ja promoguts, aptes, idòneus e suficients, no precedint demèrit o causa justa, són així palanquejats e sostreits de llurs oficis?» (citat per GarciaOliver 2016: 205-206).

5. Era comú usar-lo com a descriptor de béns en inventaris, com una arpa «sotil, descordada e sens timblans e clanilles» (Ferrer Gimeno 20I9: II4). I no sols d'objectes. També s'emprava per a caracteritzar indignament persones. Una bona mostra d'això s'evidencia en la disputa que va enfrontar les confraries valencianes de Sant Jaume i de Santa Maria el 1393 amb motiu de la precedència en el funeral de la infanta Elionor, filla de Joan I i Violant de Bar. Llavors, els confrares de Sant Jaume argumentaren que la seua associació era la més antiga i, com a tal, estava dotada de majors privilegis. En conseqüència, no podien consentir que els membres 
amb el nostre objecte d'estudi es troben glossades en l'exhaustiva obra d'Alcover-Moll, on es defineix: «Agut, penetrant, que distingeix (mentalment o sensualment) coses o matisos molt fins i difícils» $i$ «Molt elevat o difícil de distingir, d'entendre o de realitzar» (DCVB, s.v. subtil). Mentre que el Diccionari de l'Institut d'Estudis Catalans especifica: «Mentalment agut, que percep fineses dificilíssimes de copsar, que estableix distincions gairebé imperceptibles». A més, a causa d'aquesta subtilesa, l'autor pot revelar «una gran agudesa mental» (DIEC2, s.v. subtil; v. DA, s.v. subtil).

No és comú trobar aquesta paraula en els registres judicials, però la redundància amb què apareix en la reproducció textual del decurs d'un juí mereix ser comentada. L'any I409 s'esdevé el plet en el qual Jaume Mateu, pintor de València i nebot del difunt Pere Nicolau, reclama a Gonçal Peris, pintor de València i curador dels béns del dit Pere Nicolau, la soldada per haver treballat catorze anys al servei del seu oncle. ${ }^{6}$ Després de l'exposició dels motius pels quals Jaume Mateu hauria de ser remunerat, el procurador de Gonçal Peris fa una rèplica i, entre els arguments que esgrimeix, hi ha el que atesta que, per raó de la seua relació de parentiu, Pere Nicolau acceptà Mateu sota la seua tutela $\mathrm{i}$, gràcies a la diligència que el mestre mostrà envers l'aprenent, Jaume Mateu «és exit abte menestral e molt soptil en lo dit offici de pintor». Així mateix, quan s'interroga el pintor Gabriel Martí, es fa ressò del mateix argument; s'aclareix que Nicolau havia mostrat major diligència en ensenyar l'ofici a Mateu a causa de ser parent i, per aquesta raó, «és exit abte e subtil maestre» (citat per Aliaga \& Company \& Tolosa 20II: 216 i 223). ${ }^{7}$

Potser siga més eloqüent quan, en suport de la demanda de Mateu, es diu que aquest «era exit subtil e sabia ja daurar e apparellar axí bé com un altre pintor» (citat per Aliaga, Company \& Tolosa 2orI: 220), és a dir, que, probablement, subtil estiga al-ludint ací al fet que coneixia les tècniques de daurar i de preparar la superfície d'una taula, dos procediments que requerien una habilitat particular. En qualsevol cas, d'una banda, per mitjà del mot abte se suggereix la capacitat i la reputació que posseeix Mateu per haver rebut l'ensenyament del pintor que dirigia l'obrador més preat de València vers l'any I400; i, d'una altra, s'infereix que, per mitjà del mot subtil, disposa d'una determinada facultat tècnica.

de la de Sant Jaume, «confraria tant novella, vel varius almoyna, e de tan sotil gent, exceptats fort pochs, vullen superbiejar e haver avantatge» (citat per Rubio Vela 2003: 29I-292).

6. Encarna Montero (2013: 58-76), en la seua tesi doctoral, fa un comentari complet de les demandes que Mateu interposa a Gonçal Peris.

7. Una altra locució eloqüent del litigi: «ésser exit sobtil menestral e abte en la dita art per les dites diligència e cura e en pus breu temps que no haguera aprés altre menestral» (citat per Aliaga, Company \& Tolosa 20II: 216 i 223).

Caplletra 70 (Primavera, 2021), p. 33-52 
Francesc Granell Sales

Els epitets dels artistes baixmedievals al servei dels poders reial i municipal

En unes altres circumstàncies el significat de subtil és més evident. Es refereix a l'agudesa mental o professional de l'autor. En la declaració que Antoni Peris du endavant en el plet s'assevera (citat per Aliaga, Company \& Tolosa 20Ir: 224):

[...] l'art de pintor és tal que si lo que.l aprén no ha subtil enteniment, per molt que faça lo mestre no.l farà covinent dexeble. Et si lo aprenent és subtil aprendrà bé lo dit offici, encara que lo mestre no·y haja gran diligència.

És a dir, que si l'aprenent no posseeix una agudesa innata, no aprendrà l'ofici per més que el mestre s'hi esforce. De fet, entre els segles XIII i Xv l'adjectiu subtil sovint s'usa com una característica d'un personatge de renom del qual se'n lloa la lucidesa de pensament. És un adjectiu que sol caracteritzar els sants en l'adaptació catalana de la Legenda Aurea de Iacopo da Varazze, les Vides de sants rosselloneses. S'hi descriu un dels pares de l'Església, sant Agustí, com a «doctor molt subtil» (Kniazzeh \& Neugaard 1977: II, 85). També és una qualitat d'un dels comtes-reis d'Aragó, Ramon Berenguer IV, en les Gestes dels Comtes de Barcelona (I268-I269) «de cor e assats leuger de persona, e humil e subtil, en son propòsit ferm» (Cingolani 2008: I07). I, segons la versió catalana del Llibre del Tresor de Brunetto Latini (c. I388), és una característica de l'emperador Justinià, qui encarregà la gran compilació jurídica romana, Corpus Iuris Civilis: "Fo lo dit Justinià hom savi molt subtil, e per sa gran saviesa abreujà les leys del Codi e de la Digesta, que primer eren en tal confusió que negun no.n podia venir a cap» (Latini 197I-I989: I, I49). ${ }^{8}$

Encara, subtil apareix com un epítet acompanyat del nom d'una personalitat artística il.lustre en el tractat del Dotzè del Crestià de Francesc Eiximenis: «Legim encara d'aquest que ell, sabent que Polus, hom subtil mecànich, havia primerament ensenyat de fer en les ciutats theatrum [...]» (Eiximenis I988: I, 87). L'aposició explicativa està elogiant la destresa d'un artífex romà cèlebre que practicava una art mecànica; i no una qualsevol, ja que els que projecten i construeixen monuments són susceptibles de rebre un elogi. En aquest sentit, per tant, s'ha d'entendre la lloança que en $\mathrm{I}_{402}$ fa el Consell de Barcelona del treball d'Arnau Bargués, mestre d'obres de la Ciutat Comtal: «molt bé e profitosament envers la ciutat s'és haüt en la dita obra, e per ço com ha feta molt bé, sobtilment e prima e gran noblesa d'aquesta ciutat més que no era arbitrat» (citat per Duran i Sanpere I973: III, 57). Subtil, per tant, pot designar la

8. Un poema de Joan Roís de Corella n'és una altra mostra: «Lo crèdit gran que de subtil entendre / vos posseïu, senyor de mi estimat, / me força dir lo dubte en mi causat, / que els sentiments no el basten a compendre. / Gràcia em feu, si dec io tant merèrixer, / per vos aquell me sia declarat, / dient me prest si mata pietat, / ni pot matar, així com vida créixer» (Roís de Corella I983: 54). 
característica d'una obra artística i una bona mostra en són els detalls que es donen de l'enllestiment del retaule de la capella de Sant Pere de la catedral de València, encarregat a Joan Reixac en I467, el qual havia de ser de «manera molt singular, subtil, rica e bella, com vós mateix confesseu que lo loch requer» (citat per Sanchis Sivera I93I: 3I).

En la Corona d'Aragó baixmedieval s'ha documentat el qualificatiu subtil en unes altres notícies que concerneixen els artistes i el seu significat apunta en els sentits esmentats fins ara: un treballador de les arts mecàniques subtil posseeix una agudesa mental que pot propiciar la facultat professional de ser refinat en la seua obra. «Axí com fa hun pintor soptil, que quan vol fer una ymaga pren a vegades una poqua de cera molla, o de argila, e farà ascí una ymaga, lo cap e los huyll» deia sant Vicent Ferrer (1932: 230) en un sermó. Convé subratllar que subtil adjectiva usualment els artistes que van mantenir un vincle, contractual o d'emparament, amb la Monarquia. L'argenter Consolí (Concelin) Blanc va estar treballant per a la casa reial a les acaballes del segle XIv. Elaborà o modificà les matrius dels segells menors, majors i secret de Pere el Cerimoniós, i confeccionà les empremtes sigil-lars de la reina Maria de Luna (Menéndez Pidal de Navascués 2007: 658-659). En 1382 el Cerimoniós ordena que la custòdia de la seu de Tortosa siga confeccionada per Consolí Blanc i no per un altre, ja que: «[...] sabem que.l feel argenter de casa nostra Consolí Blanch, de Alemanya, és un dels suptils maestres de la sua art qui sien en nostra senyoria segons que.ns ha mostrat experiència de sa obra la qual ha feta a nós» (citat per Sagarra 1916: I, I78).

El fet que es preveja la possibilitat que el monarca estiga exagerant la disposició i perícia de Consolí Blanc perquè vulga persuadir els receptors del missatge no lleva que el rei el tenia en consideració com un argenter fidel i, també, refinat, atés que havia observat els seus treballs sigil.lars, tasques que exigeixen matisos tècnics tènues. Era habitual que Pere el Cerimoniós donara compte, en la documentació, de la lleialtat que li demostraven els artistes, així com de les destreses que posseïen, com ja hem vist en aquests i uns altres testimonis. La diligència que el Cerimoniós posava en l'organització de la cancelleria i en l'expedició de documents per part d'aquesta — des de la decisió inicial de redactar-los fins a l'aposició del segell- evidencia que el rei atenia meticulosament aquestes qüestions (Sevillano Colom 1950: 200-204). D'aquesta manera el rei manifestava els seus coneixements artístics i s'enaltia a si mateix palesant que contractava els serveis d'uns artífexs virtuosos, els quals arribaven a estar sota la seua tutela.

Es pot demostrar quan es referia als primers mestres encarregats del magne projecte del panteó reial del monestir de Poblet (Bracons i Clapés 1989; Molina i Figueras 2013: 232-24I), Aloi de Montbrai i Jaume Cascalls, el nom dels quals sovint anava precedit de la fórmula: «fidelibus de domo nostra» (citat per Rubió i Lluch

Caplletra 70 (Primavera, 2021), p. 33-52 
Francesc Granell Sales

Els epitets dels artistes baixmedievals al servei dels poders reial i municipal

2000: II, I03). ${ }^{9}$ L'expressió «de domo nostra» palesa que l'artífex treballava amb certa freqüència per a la casa reial i, en conseqüència, podia ser emparat per la Monarquia quan així es considerara. Només cal recordar la notícia, ja mencionada, en què el monarca defensa Domingo Valls davant els prohoms d'Albocàsser: «entre vosaltres sia ben tractat axí com aquell qui és de casa nostra, e mal ne dampnatge o injúria alguna no li façats» (citat per Aliaga, Company \& Tolosa 2005: 223).

L'actitud de la seua esposa, la reina Elionor de Sicília, envers l'apreciació dels artífexs de la cort va ser semblant. En una missiva datada l'any I36I, la reina considera Aloi de Montbrai «sculptori suo» (citat per Rubió i Lluch 2000: II, 6I); a més, Llorenç Saragossà, qui fou — segons Pere el Cerimoniós - el millor pintor de la ciutat de Barcelona, era anomenat familiar seu (Falomir 1996: I88). Per una part, la hipèrbole millor estava destinada als artistes que el rei d'Aragó valorava com a preeminents, com anys després ho va ser Lluís Dalmau (Fuchs 1982: 48), pintor «de la casa del rei» enviat per Alfons el Magnànim als comtats flamencs (Tramoyeres 1907: 570; Cornudella 2009-20IO: 46), o per als artistes que el poder municipal preava pels serveis prestats en pro de l'urbs, com Genís Clot, «un dels mellors e lo mellor maestre de fusta que sia tota vostra senyoria» (citat per Sanchis Sivera 1924: I5). Per una altra, si bé el reconeixement com a familiar no suposava un grau del funcionariat reial, sí que era un títol de distinció atorgat amb motiu de la lleialtat dispensada i que estimulava els serveis de l'intitulat en els temps esdevenidors (Vincke 1964: 334).

Requerits i emparats per la cort o per les elits ciutadanes perquè enriquien l'escenari artístic, els elogis dels artífexs mitjançant la paraula subtil indicaven, almenys aparentment, que eren reconeguts per la seua lucidesa i per la seua minuciositat tècnica. Tanmateix, l'adjectiu també acompanyava un nom per a lloar la perícia de l'artista. Subtil enginy referia a la perspicàcia $(D A$, s.v. subtil), a l'«agudesa d'enteniment; aptesa per a trobar els mitjans d'aconseguir o executar les coses» ( $D C V B$, s.v. enginy; v. DECLC, s.v. enginy). ${ }^{10}$ En 1355 Pere el Cerimoniós — una vegada més - escriu una carta al pintor Francesc Jordi (citat per Rubió i Lluch 2000: I, I69), qui havia sigut recomanat al rei amb motiu de «subtilitate ingenii in arte vestra», per a fer-lo sabedor

9. Una altra referència es pot trobar en la mateixa compilació de Rubió i Lluch (2000: I, I24). Sobre l'escultor Aloi de Montbrai, vegeu l'estudi d'Emma Liaño (20I3-20I4).

Io. Curt Wittlin (I991: 538) recull aquesta accepció de subtil a l'obra De officis de Ciceró, en la traducció catalana. Un altre punt important és que aquesta és una aptitud que en el regne de França va tenir un significat concret en l'àmbit de la producció artística: engin designava la capacitat de treballar en múltiples suports artístics i la d'usar la memòria amb l'objectiu que el producte final fes evident el caràcter virtuós de l'artista i sorprenguera el client (Perkinson 2002: 56-58). 
que ell gaudirà dels privilegis propis del familiars i domèstics de la casa reial com a pintor d'armes del monarca:

Nos Petrus etc. quia vos Franciscus Georgii, pictor civitatis Barchinone, commendatus fuistis apud nos relacione veridica de subtilitate ingenii in arte vestra, super quo etiam certos quodommodo rei experiencia nos efecit, igitur ut quanto vos favoris nostre graciam sentientis tanto plus attendamini ad aplaudendum nobis singulari subtilitate, cum casus ocurreret in artificio picturarum, tenore presentis carte nostre vos dictum Franciscum in domesticum et familiarem nostrum et in specialem pictorem armorum nostrorum assumimus aliisque nostris domesticis et familiaribus agregamus, volentes quod vos sitis pictor nostrorum armorum et gaudeatis universis et singulis prerogativis, graciis et favoribus quibus alii nostri familiares et domestici gaudent et soliti sunt gaudere. Mandantes per presentem officialibus et subditis nostris quibuslibet presentibus et futuris, quatenus vos dictum Franciscum pro domestico et familiari nostro, ac pictorum armorum nostrorum habeant, teneant et tractent, vosque ut domesticum et familiarem nostrum preservent a molestiis et gravaminibus quibuscumque [...]

Un altre substantiu que acompanya el nostre adjectiu és enteniment, el qual es defineix com la "facultat de comprendre, de discernir, de raonar" (DCVB, s.v. enteniment). I en aquest sentit s'ha d'entendre el — ja citat — subtil enteniment que Antoni Peris esmenta en la declaració del plet entre Jaume Mateu i Gonçal Peris (citat per Aliaga, Company \& Tolosa 20Ir: 224). Altrament —i per acabar-, subtil artifici s'empra per a descriure un producte artístic tènue en el Tirant lo Blanch: «de un brial de domàs groch, les obres del qual eren perfilades per art de molt subtil artifici de robins, diamans, safirs e maragdes» (Martorell 2004: I439). ${ }^{11}$ I és que, en aquest cas, com en uns altres citats en diversos testimonis arreu de l'Europa medieval, artifici designa el conjunt d'habilitats manuals entrenades (Perkinson 2002: 55). ${ }^{12}$ En conseqüència, Joanot Martorell s'està referint a l'evidència d'una praxi artística ben treballada i refinada.

\section{CONCLUSIONS}

La possible intencionalitat de les notícies documentals impel-leix a no considerar totes les lloances de les destreses artístiques com uns descriptors inequívocs de

II. En un altre moment, quan es descriu el fantàstic castell del déu Amor, se cita: «entram dins un gran pati tot entorn enparamentat de draps de raç, lavorats d'or e de seda e de fil d'argent, de diverses històries, les ymatges fetes per art de subtil artifici» (Martorell 2004: 227).

I2. Segons Giovanni Pontano, un dels humanistes que va servir a la cort napolitana del rei Alfons el Magnànim, aquesta aptitud fou tinguda en consideració per part del dit monarca, ja que aprecià especialment l'excel.lència artística de Jan van Eyck justament pel seu artifici: «Nonnunquam etiam artificium ipsum commendat munera: quid tam habuit in delitis idem hic Alfonsus, quam tabellam Ioannis pictoris?» (citat per Cornudella 2009-20I0: 39). 
Francesc Granell Sales

Els epitets dels artistes baixmedievals al servei dels poders reial i municipal

la realitat. La recomanació d'un artífex per a un treball, la defensa d'un tutelat o els judicis de valor citats en un plet són declaracions circumstancials sospitoses d'exaltar un subjecte amb una finalitat determinada. Però aquestes i unes altres situacions no neguen el fet que el patró o el client apreciàs de veritat l'artista en qüestió. L'estima per la seua perícia s'esbrina a través d'unes paraules que contenien significats eloqüents. Un artista apte posseeix la capacitat per a escometre un treball determinat. Però s'ha adverat que, en ocasions, aquesta definició del terme ha de completar-se per a ser més exacta, ja que l'ús reiterat de l'adjectiu a l'hora de descriure individus d'un estatus superior, sobretot de nobles i de cavallers, és significatiu. D'aquests es subratlla, precisament, la seua condició honorable i digna; és per això que no s'ha de menystenir la possibilitat que apte puga referir-se no sols a l'artista capacitat, sinó també reputat. D'altra banda, l'adjectiu subtil s'empra per a designar l'agudesa mental d'un artífex per a exercir el seu ofici. No debades, s'usa amb freqüència per a especificar les qualitats intel-lectuals de personatges històrics cèlebres. Se'n pot inferir, però, un segon significat complementari. Junt a l'agudesa mental o, justament per raó d'aquesta, l'artista pot posseir l'habilitat tècnica de ser refinat; la facultat de distingir matisos d'una manera escrupolosa.

Cal puntualitzar que no hi ha una nòmina d'artistes lloats a causa de la manera naturalista de representar la realitat o de retratar un individu, dos axiomes fonamentals de la cultura visual del Renaixement que han estat mitificats per la historiografia (Didi-Huberman I994: 392 i ss.). Certament, aquestes mostres d'estima per la perícia de l'artista indueixen a creure que la consideració tècnica, inclús social, de les arts mecàniques no era homogènia. Determinades activitats manuals exigien talent i tècnica i, en conseqüència, eren valorades per sobre d'altres. ${ }^{13}$ És més, qualsevol persona no podia assolir-les perquè, com s'ha dit més amunt: «l'art de pintor és tal que si lo que.l aprén no ha subtil enteniment, per molt que faça lo mestre no.l farà covinent dexeble». La concreció i particularització d'uns epítets laudatoris remarquen la preferència per una personalitat artística que la Monarquia i el poder executiu municipal contractaven amb l'objectiu que servís els seus interessos. És difícil discernir si en la Corona d'Aragó hi hagué una veritable competició entre ambdues institucions per comptar amb els

I3. És escaient de mencionar que Milagros Cárcel Ortí i Juan Vicente García Marsilla subratllen el fet que els organitzadors de l'entrada a València del rei Ferran d'Antequera (I4I4) conformaren tres grups de treball diferents que corresponien respectivament a: pintors decoratius, pintors figuratius i «los del pinzell», un grup d'elit encapçalat per Gonçal Peris, anomenats així per disposar d'una major perícia tècnica (Cárcel Ortí \& García Marsilla 2013: 19-22). 
millors artistes, com va ocórrer, per exemple, en els Països Baixos (Warnke 1993: 14-33). ${ }^{14}$ En qualsevol cas, tant la figura del pintor de cort com la del pintor de ciutat (Falomir I996b: I87-I92; Vidal 20I2) esdevenien cabdals a l'hora de potenciar llurs imatges i llurs escenaris (Espańol 200I). Consegüentment, l'adulació de la capacitat operativa de l'artista enfortia un vincle que convenia a tots dos, el contractat i el contractant.

De la institució monàrquica destaquen, en aquest sentit, el rei Pere el Cerimoniós i la seua cancelleria, actors històrics distingits en el procés d'adjectivar els artistes per les seues destreses. La qualificació assídua d'aquells que eren tutelats pel rei connectava amb el seu costum de controlar la redacció i presentació dels documents (Gimeno Blay 2006) i, encara que els que s'han exposat tenien una difusió exigua, repercutien en el fet d'utilitzar les arts com un mitjà per a fonamentar el prestigi i l'autoritat règies. Una operació que es constata al llarg del seu regnat en la promoció i la supervisió directa de projectes artístics solemnes que glorificaven tant la dinastia del casal com la seua pròpia imatge davant els súbdits contemporanis i esdevenidors. Llavors, s'assolí l'apoteosi de la imatge del rei en la Corona d'Aragó (Molina i Figueras 2013). Tanmateix, aquestes qüestions no s'adveren únicament a partir de les paraules apte i subtil. Hi ha uns altres epítets que descriuen les qualitats dels artífexs. A tall d'exemple, i detectats amb menor freqüència, musa o sabut es refereixen, respectivament, a un treball meticulós i a la qualitat de posseir el coneixement (Serra Desfilis 201r: 66-67). Ajornem l'anàlisi més acurada d'aquests i uns altres mots per a treballs futurs.

Francesc Granell Sales

Universitat de València

francesc.granell@uv.es

ORCID: 0000-0002-3530-5408

\section{ABREVIATURES}

DA: Aguiló i Fuster, M. (1988-1989) Diccionari Aguiló: materials lexicogràfics, ed. a cura de Pompeu Fabra i Manuel de Montoliu, Barcelona, Alta Fulla.

DECLC: Coromines, J. (I988-200I) Diccionari etimològic i complementari de la llengua catalana, Barcelona, Curial.

I4. En la Corona d'Aragó, els municipis pretenien imitar les accions del monarca per a congraciar-se amb ell, mentre que la competitivitat s'esdevenia entre les pròpies ciutats de la Corona (Miquel 2008: 69-78).

Caplletra 70 (Primavera, 2021), p. 33-52 
Francesc Granell Sales

Els epitets dels artistes baixmedievals al servei dels poders reial $i$ municipal

DCVB: Alcover, A. M. \& Moll, F. B. (200I-2002) Diccionari català-valencià-balear [versió electrònica: $<$ http://DCVB.iec.cat/>].

DIEC2: Diccionari de l'Institut d'Estudis Catalans [versió electrònica de la 2a edició: $<$ http://dlc.iec.cat/>].

\section{REFERÈNCIES BIBLIOGRÀFIQUES}

Alcoy, R. (2005) «Llorenç Saragossa», en A. Pladevall i Font (dir.), L’Art Gòtic a Catalunya. Pintura I. De l'inici a l'italianisme, Barcelona, Enciclopèdia Catalana, p. 250-253.

Aliaga, J. (2009) «La potencia expresiva del gótico internacional valenciano», en X. Company, M. J. Vilalta \& I. Puig (coord.), El rol de lo hispano en la pintura mediterrània de los siglos XV y XVI, Lleida, Garsineu/CAEM, p. I68-I9I.

Aliaga, J., X. Company \& Ll. Tolosa (2005) Documents de la pintura valenciana medieval i moderna I (I238-I400), València, Universitat de València.

- (20II) Documents de la pintura valenciana medieval i moderna III (I400-I425), València, Universitat de València.

Arciniega García, L. (1995) «Lorenzo Zaragoza, autor del retablo mayor del Monasterio de San Bernardo de Rascaña, extramuros de Valencia (1385-1387)", Archivo de Arte Valenciano, 76, p. 32-40.

Arnall i Juan, M. J. (2000) Lletres reials a la ciutat de Girona, Lleida, Pagès.

Bracons I Clapés, J. (1989) "Operibus monumentorum que fieri facere ordinamus. L'escultura al servei de Pere el Cerimoniós», en J. Ainaud de Lasarte et alii (ed.), Pere el Cerimoniós i la seva època, Barcelona, CSIC / Departament d'Estudis Medievals, p. 209-236.

Cárcel Ortí, M. M. \& García Marsilla, J. V. (20I3) Documents de la pintura valenciana medieval i moderna IV. Llibre de l'entrada de Ferran d'Antequera, València, Universitat de València.

Cingolani, S. M., ed. (2008) Gestes dels comtes de Barcelona i reis d'Aragó, València, Universitat de València.

Cornudella, R. (2009-20IO) «Alfonso el Magnánimo y Jan van Eyck. Pintura y tapices flamencos en la corte del rey de Aragón», Locus Amoenus, Io, p. 39-62.

Didi-Huberman, G. (1994) «Ressemblance mythifiée et ressemblance oubliée chez Vasari: la légende du portrait sur le vif", Mélanges de l'Ecole Française de Rome. Italie et Méditerranée, CVI, 2, p. 383-432.

Dubreuil, M. H. (1987) Valencia y el gótico internacional, València, Institució Alfons el Magnànim. 
Duran i Sanpere, A. (1973) Barcelona i la seva història, vol. III, Barcelona, Curial.

Eiximenis, F. (1988) Dotzè llibre del Crestià, ed. a cura de Curt Wittlin, Girona, Collegi Universitari de Girona.

Ensenyat Pujol, G. (1997) La reintegració de la Corona de Mallorca a la Corona d'Aragó (I343-I349), Mallorca, Moll.

Español, F. (I997) «La transmisión del conocimiento artístico en la Corona de Aragón (siglos XIV-Xv)», Cuadernos del CEMYR, 5, p. 73-II4.

- (200I) Els escenaris del rei: art i monarquia a la corona d'Aragó, Manresa, Angle.

Falomir, M. (1996) «Sobre los orígenes del retrato y la aparición del pintor de corte en la España bajomedieval», Boletín de Arte de la Universidad de Málaga, I7, p. I77-I96.

- (I996b) Arte en Valencia (I472-I522), València, Consell Valencià de Cultura.

FERrando, A. (1983) Els certàmens poètics valencians del segle XIV al XIX, València, Institució Alfons el Magnànim.

- ed. (2007), Curial e Güelfa, Toulouse, Anarchasis.

Ferrer Gimeno, M. R. (20I9) «El Llibre de la Çuna e Xara en dos bibliotecas valencianas del siglo XV», Medievalia, 22, p. 89-I26.

Fuchs, A. S. (I982) «The Virgin of the Councillors by Dalmau (I443-I445), the contract and its eyckian execution", Gazette des Beaux Arts, 99, p. 45-54.

García Marsilla, J. V. (2OII) «Narrar amb imatges: la pintura de retaules i la comunicació visual a la València del segle XV», en R. Bellveser (coord.), La novel.la de Joanot Martorell i l'Europa del segle XV, p. I43-I63.

- (2015) «La juventud valenciana del pintor Lorenzo Zaragoza a la luz de un nuevo hallazgo documental», en F. Ruiz i Quesada (ed.), Viatges a la bellesa. Miscellània homenatge a Maria Rosa Manote i Clivilles, Barcelona, Retrotabulum Maior, p. I03-I08.

Garcia-Oliver, F. (20I6) Valencians sense ADN, València, Edicions $3 \mathrm{i} 4$.

Gimeno Blay, F. M. (2006) Escribir, reinar: la experiencia gráfico-textual de Pedro IV el Ceremonioso (1336-I387), Madrid, Abada.

IZQUiERdo ArANDA, T. (20I3) «Un palacio para un héroe: la representación del Sagrado Palacio Imperial de Constantinopla en el Tirant lo Blanc», Anales de Historia del Arte, 23, p. 487- 497.

Kniazzeh, C. S. M. \& NeugaArd, E. J., ed. (I977) Vides de sants rosselloneses, vol. III, Barcelona, Rafael Dalmau.

LAIrón Pla, A. J., ed. (200I) Libre de diverses statuts e ordinacions fets per lo consell de la vila de Algezira, València, Universitat de València.

LATini, B. (I97I-I989) Llibre del tresor, ed. a cura de Curt Wittlin, Barcelona, Barcino. 
Francesc Granell Sales

Els epitets dels artistes baixmedievals al servei dels poders reial $i$ municipal

Liaño, E. (20I3-20I4) «Aloy de Montbrai imaginator. Del Reino de Francia a la Corona de Aragón en el siglo XIV», Locus Amoenus, I2, p. 29-53.

Llanes Domingo, C. (20I2) «El Gòtic Internacional a València. Antoni Peris en la pintura valenciana (I402-I424)", Ars Longa, 2I, p. 95-IIO.

López Rodríguez, C. (2004) Epistolari de Ferran I d'Antequera amb els infants d'Aragó $i$ la reina Elionor (I4I3-I4I6), València, Universitat de València.

Madurell i Marimón, J. M. (I952) «El pintor Lluís Borrassà: su vida, su tiempo, sus seguidores y sus obras», Anales y Boletin de los Museos de Arte de Barcelona, IO, p. 9-365.

Marr, A., R. Garrod, J. R. Marcaida \& J. Oosterhoff (2019) Logodaedalus. Word Histories of Ingenuity in Early Modern Europe, Pittsburgh, University of Pittsburgh Press.

Martorell, J. (2004) Tirant lo Blanch, ed. a cura d'Albert Hauf, València, Tirant lo Blanch.

MenéNdez Pidal de Navascués, F. (2007) «Le deuxième sceau de majesté de Charles II de Navarre. Histoire d'une matrice deux fois regravée», en J. Martínez de Aguirre (ed.), Homenaje a Faustino Menéndez Pidal de Navascués, Pamplona, Príncipe de Viana, p. 655-664.

Miquel Juan, M. (2008) Retablos, prestigio i dinero: talleres y mercado de pintura en la Valencia del gótico internacional, València, Publicacions de la Universitat de València.

Molina i Figueras, J. (2013) «La memoria visual de una dinastía. Pedro IV el Ceremonioso y la retórica de las imágenes en la corona de Aragón (I336-1387)», Anales de Historia del Arte, XXIII, 2, p. 219-24I.

Montero Tortajada, E. (2013) «La transmisión del conocimiento en los oficios artísticos. Valencia, I370-I450", València, Departament d'Història de l'Art de la Universitat de València, tesi doctoral inèdita.

Mortet, V. (I9II) Recueil des textes relatifs à l'histoire de l'architecture et à la condition des architectes en France au Moyen Age. X'-XI siècles, París, Picard.

Muratova, X. (1986) «Vir fallax et falsidicus sed artifex praeelectus: remarques sur l'image sociale et littéraire de l'artiste au Moyen Age», en X. Barral i Altet (ed.), Artistes, artisans et productions artistiques au Moyen Age, vol. I, París, Picard, p. 53-72.

Oliver, B. (1929) Excitatori de la pensa de Déu, ed. a cura de Pere Bohígas, Barcelona, Barcino.

Perkinson, S. (2002) «Engin and artifice: Describing Creative Agency at the Court of France, ca. I400», GESTA, xLI, I, p. 5I-67. 
Pitarch, A. J. (1979) «Llorens Saragossa y los orígenes de la pintura medieval en Valencia", D'Art, 5, p. 2I-50.

-(I98I) «Llorenç Saragossa y los orígenes de la pintura medieval», D'Art, 6-7, p. IO9-II9.

- (200I) «Los primeros tiempos (siglo XIII - último tercio del siglo XIV», en La luz de las imágenes, València, Generalitat Valenciana, p. 97-I47.

Roís de Corella, J. (1983) Obra profana, ed. a cura de Jordi Carbonell, València, Edicions $3 \mathrm{i} 4$.

Rubio Vela, A. (2003) Epistolari de la València medieval, vol. I, València/ Barcelona, Institut Interuniversitari de Filologia Valenciana / Publicacions de l'Abadia de Montserrat.

Rubió I Lluch, A. (2000) Documents per a la història de la cultura catalana medieval, vol. II, Barcelona, Institut d'Estudis Catalans.

Sagarra, F. (1916) Sigil.lografia catalana: inventari, descripció $i$ estudi dels segells de Catalunya, vol. III, Barcelona, Estampa d'Henrich.

Sanchis Sivera, J. (1924) «La escultura valenciana en la Edad Media», Archivo de Arte Valenciano, Io, p. 3-29.

- (1931) «Pintores medievales en Valencia», Archivo de Arte Valenciano, I6/I7, p. 3-II6.

Sant Vicent Ferrer (1932) Sermons, ed. a cura de Josep Sanchis Sivera, Barcelona, Barcino.

Saralegui, L. (1952) «La pintura valenciana medieval. Andrés Marzal de Sax (Cont.)», Archivo de Arte Valenciano, 23, p. 5-39.

- (1954) «La pintura valenciana medieval. Andrés Marzal de Sax (Cont.)», Archivo de Arte Valenciano, 25, p. 5-33.

Schlosser, J. (1896) Quellenbuch zur Kunstgeschichte des abendländischen Mittelalters, Viena, Ministeriums für cultus und unterricht im vereine mit fachgenossen [<https://digi.ub.uni-heidelberg.de/diglit/schlosserı896/oooI/thumbs >].

Serra Desfilis, A. (1994) «Al servicio de la ciudad: Joan del Poyo y la práctica de la arquitectura en Valencia (I402-I439)", Ars Longa, 5, I994, p. III-II9.

- (2005) «El espejo roto. Las imágenes del caballero: del Tirant al Quijote», en N. Piqueras (coord.) Del Tirant al Quixot: la imatge del cavaller, València, Universitat de València, p. 19-52.

Sevillano Colom, F. (1950) "Apuntes para el estudio de la Cancillería de Pedro IV el Ceremonioso", Anuario de Historia del Derecho Español, 20, p. I37-24I.

- (20II) «Promotores, tradición e innovación en la arquitectura valenciana del siglo xv», Goya, 334, p. 58-73.

Tramoyeres, L. (1907) «El pintor Dalmau. Nuevos datos biográficos», Cultura Española, 6, p. 553-580. 
Turell, G. (1992) Arbre d'Honor, ed. a cura de Cecília Burgaya, Barcelona, Barcino. VIDAL, J. (20I2) «Brandons, llibres, entremesos i altres arreus (la creació del càrrec de pintor de la ciutat de Barcelona i a Tortosa i les seves funcions)", en CEHA. XVII Congreso Nacional de Historia del Arte. Art i memòria, Barcelona, Atrio, p. I718-173I.

VINCKE, J. (1964) «Los familiares de la corona aragonesa alrededor del año I300», Anuario de Estudios Medievales, I, p. 333-35I.

Warnke, M. (1993) The Court Artist. On the Ancestry of the Modern Artist, Cambridge, Cambridge University Press.

WitTlin, C. (199I) Repertori d'expressions multinominals i de grups de sinònims en traduccions catalanes antigues, Barcelona, Institut d'Estudis catalans. 